\title{
AGILE METHODOLOGY SCRUM: REPORT OF AN EXPERIENCE IN THE FIRST CONTACT WITH PROGRAMMING LANGUAGES IN A UNIVERSITY COURSE OF COMPUTER SCIENCE
}

\author{
Sónia Rolland Sobral ${ }^{1}$ \\ ${ }^{1}$ Univeridade Portucalense (Portugal)]
}

\begin{abstract}
Algorithms and programming is the initial curricular unit in a computer science degree; it's where there is a first contact with thinking algorithmic and a programming language. Always a high rate of failure, often accompanied by abandonment. The workgroup presents itself as an attempt for the students to gain interest in the unit, as well as to improve their skills.

This article is part of an investigation that intends to see the benefits of an agile methodology such as SCRUM associated with the project. The agile SCRUM methodology was chosen because its characteristics fit the expected objectives. The principles of rugby scrum are used as a methodology for group work in software projects.

The constitution of the groups was imposed and not chosen by the students. Initially 55 students were enrolled in the curricular unit: 11 groups with 5 students each. The work consisted of three parts (each submitted into MOODLE). In the three phases of the project each student had to complete two surveys: one at the beginning of each phase and one at the end of each of the three phases. A final evaluation was requested in the form of an inquiry.
\end{abstract}

On the day of the final presentation, almost all the students said they really liked the group work and explained that they worked much harder in time and effort to do the work than in the tests.

Keywords: introduction to programming; scrum; work group.

\section{THE CURRICULAR UNIT}

Algorithms and programming is the introductory curricular unit to programming for students entering a degree in computer science. It is a curricular unit that traditionally presents high failure rates, often accompanied by the students' early abandonment [1]. The teachers have to adapt their way of teaching to the current students and their characteristics [2]. This article is part of an investigation that seeks to see the benefits of an agile methodology such as SCRUM associated with group work [3]. In this curricular unit a problem-solving approach is made, using top-down algorithms, tracings, and the C programming language [4].

\section{SCRUM}

Rugby is a sport that most people admire for its particularities and teachings for life in society. Despite being a collective sport with physical contact has a code of ethics and a set of values that differentiate it from other sports: Respect, Integrity, Passion, Solidarity and Discipline [5]. One of the ways to start the game is the scrum (eight players): a first row (two props and the hooker), a second row (usually with four players, 6, 4, 5 and 7) and finally a third row (number 8 ) in the final position. The props should be attached to the hooker that holds the props with both arms, while the second line players must cling to the first row player in front of them. The last player (number 8) must hold the second row with his arms. Scrum is an example of teamwork: if one of the players loses strength or if the team is deconcentrated, the team will lose the ball [1]. The scrum is a form of agile approach. The principles of the Rugby scrum have been withdrawn for project management, particularly in software development, which has been extensively studied. The features initially intended for a project are initially defined but may change [6]. 


\section{RULES OF EVALUATION}

In the first class of the semester we presented to students the evaluation formula of the curricular unit: three tests and one group project $(20,25,30$ and $25 \%$ of the final grade, respectively) in continuous evaluation; one exam and one project ( 75 and $25 \%$, respectively) in the other special assessments. The tests / exams would be carried out in laboratory: a written part and a part of programming in C.

\section{RULES OF PROJECT GROUP}

The project consisted of three parts (each with submissions in the initial project plan MOODLE (after the Sprint Planning Meeting), the final algorithm and the final sprint program in C) and a presentation / talk at the end of the semester. In the three phases of the project each student was asked to complete two surveys: one at the beginning of each phase and one at the end of each of the three phases). A final evaluation was requested in the form of an inquiry on the day the paper was submitted.

The SCRUM principles and agile methodologies were explained to the students:

- The players and roles: the scrum owner, the team and the scrum master.

- What is a Product Backlog (all desired features for a product): the project was divided into three parts (sprints) and each part accompanied the semester. Each stage worked as an upgrade from the previous phase.

- Submission dates for each of the sprints backlogs (report what will be done in this phase).

- Submission dates of each of the finished sprints, MOODLE (algorithm and sprint scheme, as well as the program in C).

The deadlines and documents to be submitted in MOODLE were defined. It was assumed that the interlocutor would be the project leader elected by the group.

\section{GROUP CONSTITUTION}

The groups of five elements were created by the teacher in the second week of classes. The distribution was made with a decreasing order of attendance in the initial classes and alphabetically in ascending order. As the working model includes evaluation of group colleagues it was decided not to allow students to form groups (often evaluation only for friendship) which would jeopardize a fair evaluation to colleagues. Initially 55 students were enrolled in the curricular unit, for which 11 groups of 5 students were created each.

\section{THE SURVEYS DURING THE PROJECT}

At the beginning of each of the three phases of work, the response to the survey was requested, as was the sprint finished submission (file in word with algorithm / schema and file with program in $\mathrm{C}$ language). The questions were:

- Number of my Group (1 to 11)

- My student number

- I like this group work (1 to 5)

- I am enjoying working with this group (1 to 5)

- I feel that I improve my Algorithm and Programming skills by working on this project (1 to 5 )

- I feel that I improve my group work skills because of this group work (1 to 5)

- My attendance at group meetings prior to today (face, skype ...) (1 to 5)

- My work in the group work since previous survey until today (1 to 5 )

- Self-assessment from the day of the previous survey until today regarding group work

- For each of the four group colleagues: 
- Colleague's Name 1 (1st and last)

- Presences of my colleagues in group meetings prior day to date (face-to-face, skype...)

- the work of my colleagues from the previous survey to date on group work

- Assessment of my colleagues from the previous survey to date on group work

\section{ANSWERS TO INVESTIGATIONS DURING THE PROJECT}

For this article we will only observe the surveys that were answered with each of the three submissions of papers.

The questions were to be answered from 1 to 5 :

S1. I like this project

S2. I enjoy working with this group

S3. I improve my skills

S4. I improve my group work skills

S5. My attendance at group meetings

S6. My work at work group

S7. Self-assessment of group work

TABLE 1. Average answers (1-5) to the questions the three surveys.

\begin{tabular}{c|c|c|c|c|c|c|c|c}
\hline \hline Step & N & P1 & P2 & P3 & P4 & P5 & P6 & P7 \\
\hline 1 & 24 & 4,04 & 4,25 & 3,88 & 3,83 & 4,50 & 4,29 & 4,08 \\
\hline 2 & 28 & 4,46 & 4,46 & 4,46 & 4,32 & 4,75 & 4,61 & 4,61 \\
\hline 3 & 24 & 4,58 & 4,29 & 4,29 & 4,42 & 4,63 & 4,75 & 4,67 \\
\hline \hline
\end{tabular}

We can verify from the previous table that the number of students who answered the surveys is less than half of the students enrolled. And that the assessments of the students are quite positive.

Questions related to colleagues, with possible answers from 0 (nothing) to 5 (excellent):

Q1. Presences of my colleagues

Q2. My colleagues' work

Q3. Evaluation of my colleagues.

In this case, averages were always obtained between 3.6 and 3.94 as shown in the following table.

TABLE 2. Average peer response (1-5), 3 surveys.

\begin{tabular}{c|c|c|c|c}
\hline \hline Step & $\mathrm{N}$ & $\mathrm{Q} 1$ & $\mathrm{Q} 2$ & $\mathrm{Q} 3$ \\
\hline 1 & 24 & 3,70 & 3,60 & 3,66 \\
\hline 2 & 28 & 3,94 & 3,90 & 3,94 \\
\hline 3 & 24 & 3,86 & 3,91 & 3,68 \\
\hline \hline
\end{tabular}

Regarding peer evaluations: it was noticed that the level 5 (excellent) was mostly answered than level 0 (Nothing), especially in the first survey. There is an evolution in the correction of the evaluations to colleagues: in the last survey there are much less level 5 marks assigned to group colleagues.

In the following table it is verified that most of the evaluations were in level 5 , the best answer. $18 \%$ the answers were 0 (the worst) for colleagues who probably did not attend work meetings. 
TABLE 3. Percentage of responses at each level 0 to 5 relative to group colleagues.

\begin{tabular}{c|c}
\hline \hline Level & $\%$ \\
\hline 0 & $17,98 \%$ \\
\hline 1 & $1,43 \%$ \\
\hline 2 & $1,21 \%$ \\
\hline 3 & $7,24 \%$ \\
\hline 4 & $10,96 \%$ \\
\hline 5 & $61,18 \%$ \\
\hline \hline
\end{tabular}

It should be noted that the grade of each of the works is attributed by the teacher with a correction of the evaluation of the classmates: that is, the grade assigned by the teacher was multiplied by the evaluation value given by the group colleagues.

\section{PROJECT}

In the three phases of the project the files requested were:

a) MsWord, beginning phase

MsWord file submitted to MOODLE, project manager

Who is the project leader?

Project description

Who appeared in the meetings (Skype, face-to-face, WhatsApp...)

How the project was divided

b) Inquiry 1

Answered in MOODLE, everyone

c) Word final phase

Submitted into MOODLE, project manager

Word with algorithm (and if necessary project scheme)

d) C file

Submitted into MOODLE, project manager

e) Inquiry 2

Answered in MOODLE, everyone

All file submissions had very strict deadlines, not accepting submissions by mail.

\section{FINAL EVALUATIONS}

Of the 55 students initially enrolled: 9 students never appeared at any time of evaluation and 13 attended less than half of the 4 assessment moments; 33 students were not missing at any time of evaluation. Of these 33 students, 28 were approved in the normal season.

Considering only these 33 students the average marks of the first test was 13.39; of the second test 13.36; of the 3rd test 6.77 and of the project 12.77; being the final average 11.24. It is then verified that the grades attributed to the work are not far from the remaining grades, even taking into account that the work grades had the correction factor of the evaluation of co-workers.

In the end, it was verified that of one of the groups did not appear any student, and that in two of the groups only one student remained, as can be seen in the following table. 
TABLE 4. Number of students who appeared in the four evaluation moments by group number.

\begin{tabular}{l|l}
\hline $\begin{array}{l}\text { Group } \\
\text { number }\end{array}$ & $\#$ \\
\hline G1 & 5 \\
\hline G2 & 4 \\
\hline G3 & 5 \\
\hline G4 & 5 \\
\hline G5 & 4 \\
\hline G6 & 4 \\
\hline G7 & 2 \\
\hline G8 & 0 \\
\hline G9 & 2 \\
\hline G10 & 1 \\
\hline G11 & 1 \\
\hline \hline
\end{tabular}

\section{FINAL QUESTIONNAIRE}

On the day of the final presentation / conversation students were asked to complete an inquiry which would have the following questions:

Q1 I liked this group work

Q2 I liked working with this group

Q3. I feel that I have improved my skills in Algorithm and Programming because of this group work

Q4. I feel that I have improved my group work skills because of this group work.

Each question answer from level 1 (nothing) to 5 (Much).

The last question, optional, was a request for suggestions.

As shown in the following figure, we obtained 20 student responses.

TABLE 5. Responses to the final survey.

\begin{tabular}{c|c|c|c|c}
\hline \hline Level & Q1 & Q2 & Q3 & Q4 \\
\hline 1 & 1 & 4 & 0 & 2 \\
\hline 2 & 0 & 0 & 0 & 0 \\
\hline 3 & 2 & 2 & 4 & 2 \\
\hline 4 & 6 & 1 & 7 & 7 \\
\hline 5 & 11 & 13 & 9 & 9 \\
\hline \hline
\end{tabular}

Only three students made suggestions:

"Maximum 3 elements per group; everything else was interesting. "' Smaller groups. "' It's preferable that everyone can choose their group colleagues. "

\section{CONCLUSIONS}

On the day of the project presentation it was found that in general terms the students really enjoyed this group work; the students said that they worked much harder in time and effort to do the work than in the tests.

Just to verify that of the 11 groups only 6 maintained at least 4 of the 5 initial students. The five dropout groups did not work objectively well, which leads us to conclude that group work is a very 
interesting methodology for students who are interested and that is hardly a way to encourage those who are disinterested.

\section{REFERENCES}

[1] S. R. Sobral, "COMPUTER STUDENTS: IDENTIFICATION OF A SUCCESS PROFILE," in 10th International Conference on Education and New Learning Technologies, Palma, 2018.

[2] S. R. Sobral, "ALGORITHMS AND INITIAL PROGRAMMING: DIFFERENT PUBLIC, DIFFERENT TEACHING-LEARNING?," in International Conference on Education and New Learning Technologies, Barcelona, 2016.

[3] S. R. Sobral and F. Moreira, "SCRUM: FROM RUGBY TO TEAMWORK IN HIGHER EDUCATION," in 11th annual International Conference of Education, Research and Innovation, Sevilla, 2018.

[4] Universidade Portucalense, "Ficha de unidade Curricular: Algoritmia e Programação," $2018 . \quad$ [Online]. https://siupt.upt.pt/aulas/ficha_uc_impressao.php?df_id=3776. [Accessed 2019].

[5] Federação Portuguêsa de Rugby, "O código do jogo de rugby," 2018. [Online]. Available:

http://institucional.fpr.pt/ficheiros_site_fpr/documentos/leis_jogo/codigo_do_jogo.pdf..

[6] K. a. S. J. Schwaber, "The Definitive Guide to Scrum:," 2017. 